\title{
Serological identification of Rickettsia spp from the spotted fever group in capybaras in the region of Campinas - SP - Brazil
}

\author{
Identificação sorológica de Rickettsia spp do grupo da febre maculosa em capivaras na região de \\ Campinas, SP, Brasil
}

\author{
Celso Eduardo de Souza ${ }^{*}$ Savina Silvana Lacerra de Souza ${ }^{I}$ Virgília Luna Castor Lima \\ Simone Berger Calic ${ }^{\text {II }}$ Maria Cecilia Gibrail Oliveira Camargo ${ }^{\text {III }}$ Elisa San Martin Mouriz Savani ${ }^{\mathrm{III}}$ \\ Sandra Regina Nicoletti D’Auria ${ }^{I I I}$ Arício Xavier Linhares ${ }^{\mathrm{IV}}$ Natalino Hajime Yoshinari $^{\mathrm{V}}$
}

\begin{abstract}
Diseases transmitted by ticks have been an important health problem all over the world. Brazilian Spotted Fever (BSF) stands for a serious epidemiological concern due to the high mortality rates pointed out. Capybaras are commonly incriminated as possible reservoirs in the BSF transmission cycle. In the last decades the numbers of these animals raised sharply and they have invaded human areas. They intensify the contact between ticks and humans beings. This study aim is to contribute to the possible role performed for this rodent in the BSF epidemiology in some areas located in Campinas region, São Paulo. Cabybaras infected by rickettsiae of BSF group were studied through the analysis of the frequencies of BSFgroup rickettisae antibodies titer $=64$ by indirect immunofluorescence test (IFA), and data from human cases epidemiological surveillance. The serum frequency positiveness varied greatly according to areas where animals were captured. However it was found serum positiviness only in the areas where human cases of BSF were reported. These findings suggest the capybara may be seen as sentinel animal. Due to presence of serological cross reactivity between microorganisms belonging to SF group, the results must be interpreted carefully and additional methods to distinguish pathogenic rickettsiae are required in our country.
\end{abstract}

Key words: Rickettsia, Amblyomma, Hydrochoerus hydrochaeris, Capybara, Spotted Fever.

\section{RESUMO}

Doenças transmitidas por carrapatos vêm sendo um importante problema de saúde pública no mundo. A Febre Maculosa Brasileira (FMB) representa um sério risco epidemiológico devido às altas taxas de letalidade apresentadas. As capivaras são freqüentemente incriminadas como possíveis reservatórios no ciclo de transmissão da FMB. Nas últimas décadas o número desses animais cresceu intensamente e eles invadiram os espaços humanos. As capivaras intensificam o contato entre carrapatos e seres humanos na medida em que se apresentam muito infestadas por estes parasitos. $O$ objetivo deste estudo é contribuir para o conhecimento do possível papel desempenhado por este roedor na epidemiologia da FMB em algumas áreas da região de Campinas, SP. Foi estudada a infecção das capivaras por rickettsias do grupo da $F M B$, por meio da análise das freqüencias de anticorpos contra este grupo, nestes animais, e dados da vigilância epidemiológica de casos humanos. A freqüencia desses anticorpos variou amplamente entre as localidades, entretanto, só foram encontrados soros com anticorpos com titulagem =64 naquelas onde havia notificação de casos humanos. Estes achados sugerem que a capivara poderá ser um animal sentinela. No entanto, devido à ocorrência de reação cruzada entre os microorganismos do grupo de FM estes resultados devem ser interpretados com cautela e são necessários métodos capazes de distinguir rickettsias patogênicas.

Palavras-chave: Rickettsia, Amblyomma, Hydrochoerus hydrochaeris, Capivara, Febre Maculosa.

\section{INTRODUCTION}

Diseases transmitted by ticks such as Lyme disease, Lyme disease like illness, babesiosis, ehrlichiosis, rickettsiosis, and arbovirosis are of major public health importance throughout the world. In São Paulo State, as well as in other parts of Brazil, few studies have been done related to diseases transmitted

'Laboratório de Carrapatos, Superintendência de Controle de Endemias (SUCEN), Mogi Guaçu, SP, Brasil. E-mail: labcarrapatos@sucen.sp.gov.br.*Autor para correspondência.

II Laboratório de Biossegurança, Fundação Ezequiel Dias (FUNED), Secretaria Estadual de Saúde de Minas Gerais, MG, Brasil.

III Laboratório de Zoonoses e Doenças Transmitidas por Vetores, Secretaria Municipal de Saúde de São Paulo, SP, Brasil.

${ }_{V}^{\mathrm{IV}}$ Departamento de Parasitologia, Instituto de Biologia, Universidade Estadual de Campinas (UNICAMP), SP, Brasil.

Laboratório de Doença de Lyme-símile - Faculdade de Medicina da Universidade de São Paulo (USP), São Paulo, SP, Brasil. 
by ticks. The Brazilian Spotted Fever (BSF) is an acute zoonotic disease with high lethality rates, causing among other symptoms, fever, skin rash and systemic clinical manifestations. The etiologic agent is Rickettisia rickettsi, a Gram-negative intracellular coccobacillum classified into the spotted fever group (SFG). It is transmitted to several mammal species by ticks, which may serve both as vectors and reservoirs, due to transovarial and transtadial transmission (TRAVASSOS \& VALLEJO, 1942a; TRAVASSOS \& VALLEJO-FREIRE, 1944-1945). The most important vector in Brazil is Amblyomma cajennense (DIAS, 1939; DIAS \& MARTINS, 1939; MAGALHAES, 1957; TRAVASSOS \& VALLEJO-FREIRE, 1944-1945).

The first human case of BSF in Campinas region was diagnosed in 1985, in Pedreira city, São Paulo State (LIMA et al., 2003). Since then, the disease has spread to others neighboring cities, and now it is considered endemic in this region, similar to Minas Gerais State where the disease was earlier studied (GALVÃO, 1988; DEL GUERCIO et al., 1996).

According to a study done from 1985 to 2000 in Campinas region (LIMA et al., 2003), the disease presents a high lethality rate of $49 \%$, since 27 patients from 47 diagnosed as BSF died. The human cases were distributed in the following cities: Pedreira $(n=19)$, Jaguariúna $(n=16)$, Lindóia $(n=1)$, Campinas $(n=6)$, Monte Alegre do Sul ( $n=1)$, Amparo ( $n=4)$, and Monte Mor (n=1). From 2001 to 2005, according to the state of São Paulo health agency more than 88 cases were diagnosed and other cities were pointed as new transmission sites. Concomitantly with the occurrence of human cases of BSF, there has been noted a steady increase in the number of capybaras, usually heavily infested with Amblyomma cajennense and Amblyomma dubitatum ticks. The surrounding local vegetation also showed the presence of a large number of immature and adult ticks of both species (SUPERINTENDÊNCIA Controle de ENDEMIAS, 2004).

In a previons study, capybaras inoculated with $\boldsymbol{R}$. rickettsii became infected, and then rickettsiae were recovered from the animal's bloodstream. Furthermore, inoculated capybaras did not develop any clinical signs of the disease (TRAVASSOS \& VALLEJO, 1942a). It was also demonstrated that ticks fed on infected capybaras also acquired infection, suggesting an important role of capybaras in maintaining the zoonotic cycle of BSF (TRAVASSOS \& VALLEJO, 1942b).

Rickettsia of the SFG has been reported infecting A. dubitatum ticks from capybaras in Pedreira city, SP(LEMOS et al., 1996). Despite of absence of a conclusive microbiological identification, it was suggested a possible role of this rodent in the epidemiological cycle of BSF.

Before the 1980's, capybaras had been extensively hunted. However, with the intervention of Brazilian environmental protection agencies, the number of these animals raised sharply, and they have invaded rural and urban areas, mainly public parks, over extensive regions of the state, and are now considered a public nuisance (ALHO, 1986). Presently, there are controversies on the actual role of capybaras in the transmission of BSF, despite the indirect evidences accumulated so far. Therefore, the present study aimed to contribute to the knowledge of the possible role of this rodent in the epidemiology of BSF in some areas located at Campinas region. It was studied the possible infection of cabybaras with rickettsiae of the BSF group and those findings were compared with data from human cases epidemiological surveillance.

\section{MATERIAL AND METHODS}

In 2000, the administrative region of Campinas counted a population of 5,357,805 humans, distributed over 88 counties (IBGE 2000).Eight areas distributed in six counties were studied. All these areas have great human circulation (six public parks, one university campus, one experimental agriculture farm). These localities were selected due to a manegement work done to take away the capybaras of those areas.

After official permission of the Federal Environment Agency (IBAMA), capybaras were captured in those areas. In Campinas county three areas participated of the study: 'Lagoa Taquaral', 'Lago do Café’ and the 'Parque Ecológico de Barão Geraldo’. In Monte Alegre do Sul county, it was studied the area 'Fazenda Experimental do Instituto Agronômico de Campinas (IAC)'; in Paulínia county, the area 'Parque Brasil 500' was studied; in Pirassununga county it was studied the area 'University of São Paulo Campus (USP)'; in Cordeirópolis county the area studied was 'Parque União'; in Valinhos county the area named 'CLT' was studied. In four of the studied areas (Lago do Café, Parque Ecológico de Barão Geraldo, Fazenda Experimental do Instituto Agronômico de Campinas and Parque Brasil 500) there were autochthnous cases of BSF registered, and in three of them (University of São Paulo Campus, Parque União, CLT) there were no cases previously. One area (Lagoa Taquaral) was examined before and after the first registered autochthonous cases of BSF.

The animals were trapped with quadrangular contention pens made with a metal screen 
and baited with food. After each trap, the animals were taken to another place or microchips were implanted to assure that each animal were analyzed just once. The percentages of studied animals were not known because the total number of capybaras in each area was not avaible. After being trapped they were kept without food for 12 hours, anesthetized with $2 \%$ xilazine chloridrate (4mg/pv) and $1 \%$ ketamine chloridrate (5mg $\mathrm{pv}^{-1}$ ), mixed in the same syringe. After blood collection, the animals were tagged at the base of the left ear with a microchip Animall TAG and those that were to be permanently removed to other areas were marked with a punch in the ear. The blood without anticoagulant were taken from the femoral vein and sera kept in tubes without anticoagulant and maintained at $-20^{\circ} \mathrm{C}$ for further serological tests. To search for antibodies against SFG rickettsiae, the indirect immunofluorescence test was done, using the $\boldsymbol{R}$. rickettsii antigen, Sheila Smith strain, from CDC Atlanta (Center Disease Control), USA. The fluorescein-conjugated anti-capybara antibody obtained in sheep was produced according to methodology described by several authors, (BEUTNER, 1965; CAMARGO, 1973; SAN MARTIN-SAVANI, 1998). Briefly, pool of capybara serum was precipitated with sodium sulphate $18 \%$ and dialysed with solution of sodium chloride $0.9 \%$. The immunoglobulins were obtained by chromatography ion exchange using DEAE-cellulose resin, and the protein fraction purity checked by immunoelectrophoresis (HUDSON et al., 1976). The protein concentration was measured by biuret reaction (Gornall et al., 1949). Sheep was immunized with a serial of 10 intramuscular inoculations (1mg prot ${ }^{-1} \mathrm{ml}^{-1}$ ) associated with Freund's complete adjuvant, with intervals of 15 days. The antiserum was analyzed quantitatively by radial immunodiffusion, and after identification of precipitating line at 1:128 dilution, the animal was bleed through jugular puncture. Then, the serum was precipitated with sodium sulphate $18 \%$ solution and purified using DEAE cellulose resin, and the anti capybara serum was conjugated with fluorescein isothiocyanate (FITC) in dialysis overnight. The excess of fluorchrome present in the serum was removed by filtration through Sephadex G-50 column. The conjugated was aliquoted and kept at -20 o C until use. Indirect immunofluorescence test

The cell suspension containing $R$. rickettsii was put on glass slides with micro syringe aid, dried during 30 minutes at room temperature, fixed with acetone for 15 minutes and incubated with capybara sera at different dilutions (1/16 -1024) during 30 minutes at $37^{\circ} \mathrm{C}$. The slides were then immersed in a recipient with PBS pH 7.4 for 5 minutes. This procedure was repeated twice and the slides were then washed in distilled water. They were left to dry out and one drop of the fluorescein-conjugated anti - capybara serum was added.

This is the first reported study where it was produced a anti-capybara conjugate. As it was not avaiable a previous stablished positive serum with determined titers, a 1/400 diluition was utilized. This conjugate diluition could detect positive titers in several serum diluitions. After that, the slides were incubated in a wet chamber at $37^{\circ} \mathrm{C}$ for 30 minutes, washed with PBS and distilled water. Finally, after being air dried, the glass slides were covered with glycerin and examined under a immuno-fluorescence microscope. It was considered serum reagent the animal whose test reacted at 1/64 dilution or a higher ones. This pattern has been utilized in human beings and animals tests (SANGIONI et al., 2005).

\section{RESULTS}

As shown in (Table 1), in three studied counties, 40 animals presented titers higher than 64 to SFG rickettsiae, including some individuals with very high titers $(512,1024)$. On the other hand, the others three counties did not have any reactive serum.

Among the five areas where human authoctonous cases of spotted fever had already been registered before capybaras blood collection (Parque Brasil 500, Fazenda Experimental IAC, Parque Ecológico Barão Geraldo, Lago do Café, Lagoa Taquaral), the prevalence of reagent animals oscillated between $7.3 \%$ and $59.4 \%$. In the three areas where no cases of spotted fever had been registered until the tests (USP, Parque União, CLT), no reactive animal was observed (Table 1).

In the 'Lagoa Taquaral' locality, in Campinas municipality, 6 capybaras traps were done in 2001, before BSF cases had been notified in 2003. None of the 37 sampled sera reacted to SFG. However the traps and collections done in the 2004 (after the first BSF reported case) resulted in 3 out of 4 (75\%) reactive animals. In CLT locality in Valinhos municipality, the tests done before the first notified case, resulted in no reactive animal. Tests were not done after cases were notified.

\section{DISCUSSION}

Prevalence values of serologic reactive capybaras in BSF endemic localities reported in the present study were similar to prevalence values 
Table 1 - Results of indirect immunofluorescence test ( IFA) in capybaras sera collected in areas of Campinas region counties and year of first notified human case of Brazilian Spotted Fever (BSF) in each area.

\begin{tabular}{|c|c|c|c|c|c|c|c|c|c|c|}
\hline Municipality & Locality & \multicolumn{2}{|c|}{$\begin{array}{l}\text { № of reactive sera / } \\
\text { № of tested sera (\%) }\end{array}$} & \multicolumn{5}{|c|}{$\begin{array}{l}\text { № of reactive sera according to serum } \\
\text { titers }\end{array}$} & $\begin{array}{c}\text { Period when } \\
\text { capybara sera } \\
\text { were colleted } \\
\text { (year) }\end{array}$ & $\begin{array}{c}\text { Year of first } \\
\text { notification of } \\
\text { BSF case }\end{array}$ \\
\hline Paulínia & $\begin{array}{l}\text { Parque Brasil } \\
500\end{array}$ & $3 / 8$ & (37.5) & 1 & 0 & 0 & 0 & 2 & 2002 & 2001 \\
\hline Monte A Sul & $\begin{array}{l}\text { Fazenda Exp. } \\
\text { I.A.C. }\end{array}$ & $24 / 45$ & (53.3) & 5 & 13 & 3 & 2 & 1 & 2001-2003 & 1997 \\
\hline Campinas & $\begin{array}{l}\text { Parque Ecol. } \\
\text { B. Geraldo }\end{array}$ & $5 / 12$ & (41.6) & 0 & 1 & 1 & 3 & 0 & 2002 & 2001 \\
\hline Campinas & Lago do Café & $22 / 37$ & (59.4) & 8* & 4 & 6 & 4 & 0 & $2002-2005$ & 2001 \\
\hline Campinas & $\begin{array}{l}\text { Lagoa } \\
\text { Taquaral }\end{array}$ & $3 / 41$ & (7.3) & $3 * *$ & 0 & 0 & 0 & 0 & 2001-2004 & 2003 \\
\hline Pirassununga & USP & $0 / 17$ & $(0)$ & 0 & 0 & 0 & 0 & 0 & 2002 & $\begin{array}{l}\text { no case } \\
\text { reported }\end{array}$ \\
\hline Cordeirópolis & Parque. União & $0 / 13$ & $(0)$ & 0 & 0 & 0 & 0 & 0 & 2003-2004 & $\begin{array}{l}\text { no case } \\
\text { reported }\end{array}$ \\
\hline Valinhos & CLT & $0 / 4$ & $(0)$ & 0 & 0 & 0 & 0 & 0 & 2000 & 2005 \\
\hline Total & & $57 / 177$ & (32.2) & 17 & 18 & 10 & 9 & 3 & & \\
\hline
\end{tabular}

* 4 of these sera were tested only until this dilution.

** These 3 sera were tested only until this dilution.

reported in studies done with other animal species (LEMOS et al., 1997; SANGIONI et al., 2005). It is worth mentioning that there are no studies about rickettsia serum test in capybaras up to now. A previous study searched for antibodies against rickettsiae of the SFG in domestic animals using indirect immunofluorescence assay in Pedreira city, São Paulo, located also at Campinas region, and found positive serology in 12 out of 33 dogs (36.3\%), and seven out of nine horses (77.8\%) (SANGIONI et al., 2005). These percentages were significantly higher than those found in animals from non-endemic areas, respectively $12.9 \%$ ( 4 out of 31 dogs) and $27.8 \%$ (3 out of 11 horses). Another study done in the same area, and in other three cities of São Paulo State, registered prevalence rates from $57.1 \%$ to $80 \%$ in horses and from 0 to $66.7 \%$ in dogs (SANGIONI et al., 2005). These findings suggest that rickettsiae of the spotted fever group circulate among the studied animals. The present study as well others done in animals, confirms the close contact of animals with ticks infected with rickettsiae of the BSF group.

It is important to point out that the indirect immunofluorescence test, despite of high sensitivity for $\boldsymbol{R}$. rickettsii, indicates only a previous or current contact with SFG rickettisae. It is known that a large number of Rickettsia species transmitted by ticks are found in dogs and rodents, and cross-react with $\boldsymbol{R}$. rickettsii (COWAN, 2000). Beside that, it was reported that in the last 15 years nine new species of rickettsiae have been discovered, including the responsible for
Japanese Spotted Fever (R. japonica), Flinder Islands Spotted Fever ( $\boldsymbol{R}$. honey), Tick bite fever of Astrakhan, African tick bite fever (R. africae), California Flea Typhus ( $\boldsymbol{R}$. felis), and others causative agents of not nominated presentations of Spotted Fevers $(\boldsymbol{R}$. mongolotimonae, $R$. slovaca, $R$. helvetica and $\boldsymbol{R}$. heilongjiangi) (ISHIKURA et al., 2003). The modern laboratorial techniques have allowed the discovery of new species of SFG rickettsiae, but routine serologic diagnostic tests are unable to discriminate the different rickettsioses.

In South America, it has been reported the presence of rickettsiae others than $\mathrm{R}$. rickettsii as causative agents of classical spotted fever. It was demonstrated that the sera of two patients diagnosed with BSF reacted against $\mathrm{R}$. felis, a species associated with the cat flea (GALVÃO et al., 2003). Likewise, clinical picture of spotted fever in three patients with history of fever, exanthema and involvement of the central nervous system, caused by $R$. felis infection diagnosed by PCR were also described (ZAVALA-VELÁZQUEZ et al., 2000).

Unfortunately, only few new studies have been published concerning South American species of rickettsiae. Forty specimens of Amblyomma dubitatum (reported as A. cooperi) were collected from vegetation in Pedreira County, and $\boldsymbol{R}$. bellii was identified in 16 of these ticks, and a new species of Rickettsia, belonging to the SFG was detected in 3 of them. This SFG rickettsia was named as COOPERI 
isolate, and is genetically similar to $\boldsymbol{R}$. parkeri, $\boldsymbol{R}$. africae, and $\boldsymbol{R}$. sibirica (LABRUNA et al., 2004). In an other study (SANGIONI et al., 2005), 600 specimens of A. cajennense were colleded in the same locality, but no rickettsiae were found infecting them. These findings are important, indicating that the presence of capybaras serum reactive to $\boldsymbol{R}$ rickettsii does not necessarily indicate that the animals have been infected with $\boldsymbol{R}$. rickettsii.

The results of the present study suggest that pathogenic rickettsiae circulate in some of the studied localities, and it is possible that the capybaras play a role in the disease cycle, therefore. Isolation and identification of the causal agent is necessary because it may be a species other than $R$. rickettsii. These findings suggest that the capybara may be seen as sentinel and the IFA test could help to map potential dangerous risk areas for BSF. However, due to presence of serological cross reactivity between microorganisms belonging to SFG, the results must be interpreted carefully and additional methods capable to distinguish pathogenic rickettsiae are required in these cases.

Similar results to the ones presented here were found in a study, where human and domestic animals serologic tests, from endemic and non-endemic areas for BSF, were compared. The study examined $100 \%$ of the horses and dogs in the studied localities. The prevalence in the endemic areas were similar to these found in the present study. In non-endemic areas, no animals were considered reagent as well (SANGIONI et al., 2005).

Efforts must be done in order to identify the rickettsia BSF causal agent, in human cases, in Campinas Region. It must be identified, also, in the capybara. With those data it could be cleared the role of capybara in the cycle. The possibility of the existence of other unidentified pathogenic rickettsia of the SFG infecting capybaras cannot be ruled out. Further studies capable to distinguish infections by pathogenic rickettsiae species must be done, because frequency of human cases is growing with spreading of geographical risk areas. Without this scientific progression, it is impossible to incriminate capybaras in the epidemiologic cycle of BSF, despite of some evidences on contrary. Studies able to elucidate the vector ticks behaviors in this area, for example, the roles played by Amblyomma dubitatum are also necessary.

Beside the above considerations, the findings in the Taquaral and CLT localities, where no reactive capybara sera were found before cases of BSF had been registered need to be discussed. The role of the ecological changes in capybara populations, mainly animal migration in the last decades on the onset of
BSF transmission needs to be further analysed. We can hypothesize that once the number of these animals raises, they migrate to indene areas. If animals with infected ticks are present among them, transmission may begin. We can at least conclude that the high serareactive prevalence found in tested animals in Taquaral locality after a case of BSF was reported, was a result of infected ticks feeding on them, in contrast to the possible absence of infected ticks in the previous year (2001).

Tick transmitted diseases are serious public health issue in Brazil and development of researches concerning these diseases is slow, and many questions remain unanswered yet. In addition, it is almost certain, that tick borne diseases in Brazil have peculiarities, reinforcing urgent adequate scientific advance in this field of knowledge to solve our questions.

\section{REFERENCES}

ALHO, C.J.R. (Criação e manejo de capivaras em pequenas propriedades rurais). Brasília, DF: EMBRAPA; DDT, 1986. 39p.

BEUTNER, E.H. et al. A new fluorescent antibody method: mixed antiglobulin immunofluorescense-staining. Nature, v.208, p.353-355, 1965.

CAMARGO, M.E. Introdução às técnicas de imunofluorescência. Revista Brasileira Patologia Clínica, v.10, p.143-171, 1973

COWAN, G. Rickettsial diseases: the typhus group of fevers a review. Postgraduate Medical Journal, v.76, p.269-272, 2000 .

DEL GUERCIO, V.M.F. et al. Febre maculosa no Município de Pedreira, SP, Brasil. Inquérito sorológico. Revista Sociedade Brasileira Medicina Tropical, v.30, p.47-52, 1996.

DIAS, E. Depositários naturais e transmissores da febre maculosa brasileira. Brasil Médico, v.52, p.269-272, 1939.

DIAS, E.; MARTINS, A.V. Spotted fever in Brazil. A summary. American Journal of Tropical Medicine and Hygiene, v.19, p.103-108, 1939.

GALVÃO, M.A. Febre maculosa brasileira em Minas Gerais e seus determinantes. 1988. 186f. Dissertação de Mestrado Epidemiologia - Escola Nacional de Saúde Pública, Rio de Janeiro, R.J.

GALVÃO, M.A.M. et al. Spotted fever rickettsiosis in Coronel Fabriciano, M.G. state. Revista Sociedade Brasileira Medicina Tropical, v.36, p.479-481, 2003.

GORNALL, A.G. et al. Determination of serum proteins by means of the biuret reaction. Journal of Biological Chemistry, v.177, p.751-766, 1949.

HUDSON, L. et al. Practical immunology. Oxford: Blackwell Scientific Publications, 1976. 298p. 
Instituto Brasileiro de Geografia e Estatística (IBGE). Censo 2000. Acessado em 13 mar. 2007. Online. Disponível na Internet: http://www.ibge.gov.br/censo.

ISHIKURA, M. et al. Phylogenetic analysis of spotted fever group Rickettsiae based on glt A, $17 \mathrm{kDa}$ and rOmpA genes amplified by nested PCR from ticks in Japan. Microbiology and Immunology, v.47, p.823-832, 2003.

LABRUNA, M.B. et al. Rickettsia species infecting Amblyomma cooperi ticks from na area in the State of São Paulo, Brazil, where brazilian spotted fever is endemic. Journal of Clinical Microbiology, v.42, p.90-98, 2004

LEMOS, E.R.S. et al. Primary isolation of spotted fever group rckettsiae from Amblyomma cooperi collected from Hydrochoeris hydrochaeris in Brazil. Memórias Instituto Oswaldo Cruz, v.91, p.273-275, 1996.

LEMOS, E.R.S. et al. Infestation by ticks and detection of antibodies to spotted fever group rickettsiae in wild animals captured in the State of São Paulo, Brazil. A preliminary report. Memórias Instituto Oswaldo Cruz, v.9, p.701-702, 1997.

LIMA, V.L.C. et al. Spotted fever in Campinas region, State of São Paulo, Brazil. Caderno Saúde Pública, v.19, p.331334, 2003.

MAGALHÃES, O. Contribuição para o conhecimento das doenças do grupo do tifo exantemático no Brasil. Rio de Janeiro, Memórias Instituto Oswaldo Cruz, v.55, n.47 p.773-777, 1957.

SAN MARTIN-SAVANI, E.M. Inquérito sorológico sobre Leishmaniose Tegumentar Americana em cães errantes do município de São Paulo, 1995-1996. $1988.70 f$. Dissertação (Mestrado em Epidemiologia) - Faculdade de Saúde Pública da Universidade de São Paulo.

SANGIONI, L.A. et al. Rickettsial infection in animals and Brasilian spotted fever endemicity. Emerging Infectious Diseases, v.11, p.265-270, 2005.

Superintendência de Controle de Endemias (SUCEN). Manual de vigilância acarológica. São Paulo: Secretaria de Estado da Saúde, 2004. p.62.

TRAVASSOS, J.; VALLEJO, A. Comportamento de alguns cavídeos (Cavia Aperea e Hydrochoerus capybara) às inoculações experimentais do vírus da Febre Maculosa. Possibilidade de esses cavídeos representarem o papel de depositários transitórios do vírus na natureza. Memórias Instituto Butantan, v.15, p.73-86, 1942a.

TRAVASSOS, J.; VALLEJO, A. Possibilidade de Amblyomma cajennense se infectar em Hydrochaeris capybara experimentalmente inoculada com vírus da Febre Maculosa. Memórias Instituto Butantan, Tomo XV, p.87-90, 1942b.

TRAVASSOS J.; VALLEJO-FREIRE A. Criação artificial de Amblyomma cajennense para o preparo da vacina contra a febre maculosa. Memórias Instituto Butantan v.18, p.145235, 1944-1945.

ZAVALA-VELÁZQUEZ, J.E. et al. Rickettsia felis rickettsiosis in Yucatán. All Lancet Journals, v.356, p.1079-1080, 2000. 